https://doi.org/10.18619/2072-9146-2019-4-8-12 УДК 635.3:575.113.2:573.6

Домблидес Е.А. *, Чичварина О.А., Минейкина А.И., Курбаков Е.Л., Харченко В.А., Домблидес А.С., Солдатенко А.B.

ФГБНУ

«Федеральный научный центр овощеводства»

143072, Россия, Московская обл., Одинцовский район, п. ВНИИССОК, ул. Селекционная, д. 14 *E-mail: edomblides@mail.ru

Ключевые слова: горчица сарептская, индау посевной, культура микроспор in vitro гомозиготные линии.

Конфликт интересов: Авторы заявляют об отсутствии конфликта интересов.

Для цитирования: Домблидес Е.А Чичварина О.А., Минейкина А.И., Курбаков Е.Л. Харченко В.А., Домблидес А.С., Солдатенко А.В. Ускоренное создание гомозиготных линий листовых культур семейства Brassicaceae Burnett в культуре микроспор in vitro. Овощи России. 2019;(4):8-12.

https://doi.org/10.18619/2072-9146-2019-4-8-12

Поступила в редакцию: 19.07.2019

Опубликована: 25.08.2019

Elena A. Domblides, ${ }^{*}$

Olga A. Chichvarina,

Anna I. Minejkina,

Evgeniy L. Kurbakov,

Viktor A. Kharchenko,

Arthur S. Domblides,

Alexey V. Soldatenko

Federal State Budgetary Scientific Institution Federal Scientific Vegetable Center

Selectionnaya str., 14, p. VNIISSOK, Odintsovo district, Moscow region, Russia, 143072

*E-mail: edomblides@mail.ru

Keywords: sarepta mustard, rocket salad, culture of isolated microspores in vitro, homozygous lines.

Conflict of interest: The authors declare no conflict of interest.

For citation: Domblides E.A., Chichvarina O.A., Minejkina A.I., Kurbakov E.L., Kharchenko V.A Domblides A.S., Soldatenko A.V. Rapid development of homozygous lines through culture of isolated microspores in leafy crops of Brassicaceae Burnett. Vegetable crops of Russia. 2019:(4):8-12 (In Russ.) https://doi.org/10.18619/2072-91462019-4-8-12

\section{Ускоренное создание гомозиготных линий листовых культур семейства Brassicaceae Burnett в культуре микроспор in vitro

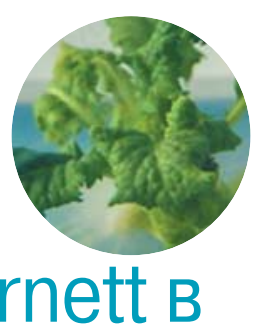

\section{АННОТАЦИЯ}

\section{Актуальность}

Для ускорения селекционного процесса и расширения генетического разнообразия необходимо вовлекать в селекционный процесс биотехнологические методы, одним из которых является метод культуры изолированных микроспор in vitro. Все большую популярность в России приобретают нетрадиционные, малораспространенные зеленные культуры семейства Brassicaceae Burnett.

\section{Материал и методика}

Объектами исследования были такие представители данного семейства, как горчица сарептская (Brassica juncea (L) Czern.) и индау посевной (Eruca sativa Mill.). Цель исследований заключалась в оптимизации базового протокола под изучаемые культуры.

\section{Результаты}

Были подобраны оптимальные условия культивирования для горчицы сарептской и индау посевного. Опытным путем был определен оптимальный для введения в культуpy in vitro размер бутона, который составил у горчицы сарептской 2,5-3,5 мм, а у индау посевного - 7,0-7,5 мм. Показано, что холодовая предобработка бутонов в течение 1 суток значительно повышает выход эмбриоидов. Для большинства образцов наиболее благоприятным оказалось сочетание pH среды NLN-13, равное 6,1, и температурная обработка $32^{\circ} \mathrm{C}$ в течение 1 суток культивирования. Все вышеперечисленные условия культивирования способствовали успешному развитию эмбриоидов. Первые деления были отмечены на 4 сутки, а уже через 2 недели эмбриоиды находились на начальной семядольной стадии развития. Выход эмбриоидов достигал у горчицы сарептской - до 25-30 шт./5 бутонов, а у индау посевного - до 5-7 шт./5 бутонов. Отмечено, что у горчицы сарептской происходит быстрое укоренение и адаптация к условиям in vivo. To есть весь процесс получения чистой гомозиготной линии составляет 4-5 месяцев, что сокращает селекционный процесс в более чем в 3 раза

\title{
Rapid development of homozygous lines through culture of isolated microspores in leafy crops of Brassicaceae Burnett
}

\section{ANNOTATION}

\section{Relevance}

Biotechnological methods are generally used to speed up breeding programs and to enhance genetic diversity, so the culture of isolated microspore in vitro can be regarded as one of very suitable methods. Nontraditional and uncommon vegetable crops belonging to Brassicaceae Burnett. are becoming more popular.

Methods

Accessions of sarepta mustard (Brassica juncea L. Czern.) and rocket salad (Eruca sativa Mill.) were taken for the study with the aim to optimize the basic protocol for these species.

\section{Results}

As a result of the study the optimum cultivation conditions have been determined for the species. Sizes of buds 2.5-3.5 mm long for sarepta mustard and 7.0-7.5 long for rocket salad which were used for cultivation had been experimentally defined. It was also shown that the cold pretreatment had improved the embryo yield. The nutritional NLN-13 medium with pH 6.1 and pretreatment at $32^{\circ} \mathrm{C}$ during a cultivation day had been shown to be more favorable for all accessions. All conditions that had been used were suitable for embryo formation. First divisions had been seen after 4 days of cultivation, while the embryos at primary cotyledonary stage only appeared after 2 weeks of cultivation. The embryo yield per 5 buds reached 25-30 and 5-7 in the sarepta mustard and the rocket salad, respectively. It is worth noticing that the root formation and plant adaptation had passed better and faster in sarepta mustard than in rocket salad. Thus, whole process of homozygous line developing can be completed for 4-5 months, making the breeding program 3 times shorter. 
Введение

последние годы все большую популярность приобретают различные зеленные культуры, ранее не имевшие широкого распространения на территории России. Огромную роль среди них играют культуры семейства Brassicaceae: индау посевной (Eruca sativa Mill.) и горчица сарептская (салатная) (Brassica juncea (L.) Czern.) $[1,2,3]$

Индау посевной известен среди потребителей также под названиями эрука, рукола, рокет-салат. Это масличная культура, обладающая пряным орехово-горчичным вкусом, листья и молодые побеги которой применяют для приготовления салатов, а семена в некоторых странах (Иране, Индии, Испании, Франции) - для приготовления горчицы.

Растение содержит алкалоиды, флавоноиды, витамин С, витамины группы В, минеральные соли, йод (до 700 мкг/кг), железо, яблочную и лимонную кислоты. Кроме того, растение богато диетическими волокнами, которые представлены гемицеллюлозой, целлюлозой и лигнином. Именно им отводится значимая роль в утилизации вредных веществ и отходов организма и снижении концентрации холестерина в крови.

В семенах содержится эфирное масло, которое выделяется после предварительной ферментации (более 1\%). Главной составной его частью является горчичное масло. Семена содержат также 25-34\% полувысыхающего жирного масла, в котором преобладает эруковая кислота (20-44\%); имеются также линолевая (12-24,9\%), линоленовая (до 17\%), олеиновая (до 18\%) и другие кислоты, стероиды ( $\beta$-ситостерин, компестерин и др.), флавоноиды (гликозиды кемпферола, кверцетина, изорамнетина) [2].

Сорт индау посевного Русалочка селекции ФГБНУ ФНЦО включен в Госреестр по Российской Федерации для выращивания в ЛПХ. Рекомендуется для использования зеленых молодых листьев в салатах и в качестве гарнира к мясным и рыбным блюдам. Раннеспелый. Высота растения 20-22 см. Лист среднего размера, лировидный, гладкий, темно-зеленый. Цветок бело-кремовый. Урожайность зеленой

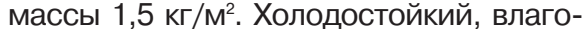
любивый [4].

Горчица - одна из важнейших в мире масличных культур и популярная зеленная культура многих стран Дальнего Востока и Юго-Восточной Азии. В России этот вид горчицы был известен в основном как пряность и возделывался с целью получения масла. В качестве салатного растения эта культура получила распространение на территории России сравнительно недавно, так же, как и в США и ряде европейских стран.

Молодые листья горчицы имеют ценный химический состав. Они богаты аскорбиновой кислотой, содержат каротин, рутин, витамины группы В, фитонциды. Острый вкус обусловлен наличием в них горчичного гликозида. Молодые листья употребляют в свежем виде в качестве салатной зелени, добавляют в мясные и рыбные блюда, а также при приготовлении различных бутербродов. Семена используют в качестве приправы для мясных и многих других блюд, а также в народной медицине. Горчица является хорошим противоцинготным средством [5]

Сорт горчицы салатной Сударушка селекции ФГБНУ ФНЦО - раннеспелый, отличается высокой товарной урожайностью $\left(3,0-3,3\right.$ кг/ $\left.\mathrm{M}^{2}\right)$. Ценность сорта - быстрое нарастание вегетативной массы, период от полных всходов до уборки на зелень составляет в среднем 35 суток. Розетка листьев полуприподнятая, высотой 70-90 см, диаметром 12-17 см. Лист среднего размера, зелёный, гофрированный. Край листа зубчатый. Масса растения - 143 г. Данный сорт рекомендуется для использования в свежем виде в качестве салатной зелени. [4].

В настоящее время в Госреестр включено более 30 сортов индау и более 20 - горчицы салатной. [4]. В то же время около 90\% свежей зелени на российских прилавках и в ресторанах составляет импортная продукция. В 2018 году импорт свежей зелени в России в денежном выражении приблизился К 100 млн долларов, а потребление по сравнению с 2015 годом увеличилось на 65\%. Наиболее крупными импортерами салатной зелени в Россию по данным на 20172018 годы являются Иран (около 28\% от всего объема ввозимой свежей зелени), Израиль (22\%), Узбекистан $(14 \%)[6,7]$.

Таким образом, огромный потенциал развития внутреннего производства свежей зелени, а также растущая высокими темпами популярность данных культур, как среди дачников, так и среди рестораторов и крупных производителей, обуславливает необходимость создания новых сортов и гибридов, отвечающих строгим требованиям современного рынка.

Для ускорения селекционного процесса и получения качественной выровненной продукции в настоящее время широко применяют биотехнологические методы, одним из которых является метод культуры изолированных микроспор in vitro. Данный метод обеспечивает не только гомозиготность получаемых удвоенных гаплоидов (DH-линий), но и способствует расширению спектра формообразования генетических рекомбинантных форм. Для растений рода Brassica L. разработан базовый протокол культуры микроспор на основе рапса [8]. В мире проведена работа рядом авторов по изучению факторов, влияющих на эмбриогенез горчицы сарептской $[9,10,11,12]$ и индау посевного [13]. Однако как показывает практика, базовый протокол необходимо модифицировать под конкретный вид, сорт и генотип.

Материалы и методы

Растительный материал и

условия выращивания

донорных растений

Объектами исследования были представители семейства Brassicaceae Burnet.: горчица сарептская сорта Сударушка и индау посевной сорта Русалочка селекции ФГБНУ ФНЦО.

Донорные растения выращивали в климатической камере при режиме $19^{\circ} \mathrm{C}$ круглосуточно, 16 ч. день/8 ч. ночь, освещение - 9000 люкс.
Для отбора бутонов, содержащих микроспоры на оптимальной стадии развития, проводили цитологическое исследование с использованием методики дифференциального окрашивания микроспор и зрелых пыльцевых зерен [14] на микроскопе Ахіо Imager A2.

\section{Культура микроспор}

Выделение и культивирование микроспор проводили по методике, разработанной в лаборатории биотехнологии ФГБНУ ФНЦО для капустных культур [15].

\section{Получение}

растений-регенерантов

Появившиеся эмбриоиды на семядольной стадии (cotyledon-stage) своего развития, помещали в чашки Петри на среду В-5 [16], содержащую $2 \%$ сахарозу и 7,0 г/л агара. Культивирование проводили на стеллажах с люминесцентными лампами при $25^{\circ} \mathrm{C}$ и фотопериоде 14 часов, освещенности 3,5 тыс. люкс.

\section{Выращивание}

растений-регенерантов

Растения с нормально развитыми листьями и корневой системой переносили в вегетационные сосуды, заполненные смесью торфа и перлита (7:3), накрывали перфорированными пластиковыми стаканчиками для адаптации растений к условиям in vivo. Выращивали растения-регенеранты в тех же условиях, что и донорные растения.

Для получения семян цветущие растения помещали в индивидуальные изоляторы и самоопыляли.

\section{Результаты}

Как показывает ряд исследований, эффективность андрогенеза в значительной степени зависит от стадии развития микроспор в момент введения в культуру in vitro. Из литературных источников известно, что у растений рода Brassica отзывчивыми считаются микроспоры на поздней стадии развития и ранние двухклеточные пыльцевые зерна $[8,17]$. Опытным путем было установлено, что у горчицы сарептской этой стадии развития соответствовал размер бутонов от 2,5 до 3,5 мм, а у индау посевного - от 7,0 до 7,5 мм. По мере развития донорного растения и его старения (цветение длится около месяца) размер бутонов, содержащих микроспоры на оптимальной стадии развития, может существенно изменяться, чаще всего в большую сторону. В связи с этим необходима постоянная корректировка размера бутонов для каждого генотипа.

В своих работах А. Тураев [18] отмечает влияние стресса, как важного фактора, оказывающего влияние на механизм репрограммирования микроспор с гаметофитного на спорофитный путь развития, с последующим образованием эмбриоидов, развивающихся во взрослое растение. В наших опытах было отмечено существенное повышение индукции эмбриогенеза из микроспор при использовании обработки бутонов пониженной положительной температурой в течение 1 суток и последующей обработкой микроспор при $32^{\circ} \mathrm{C}$ в течение 1 суток. 


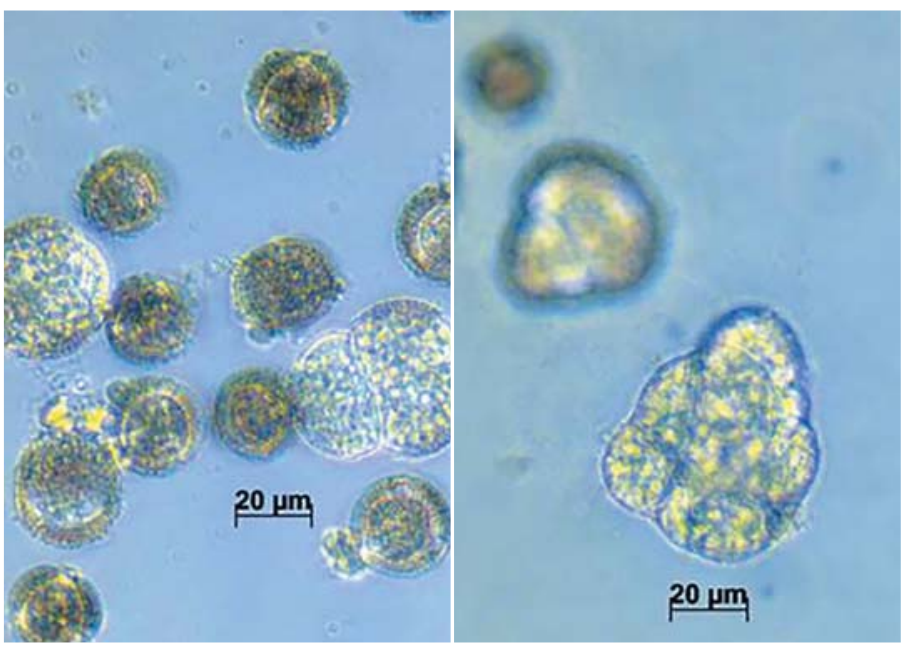

$\boldsymbol{A}$

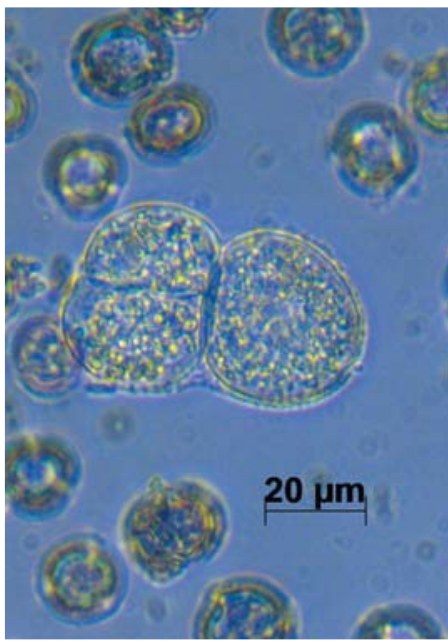

Д

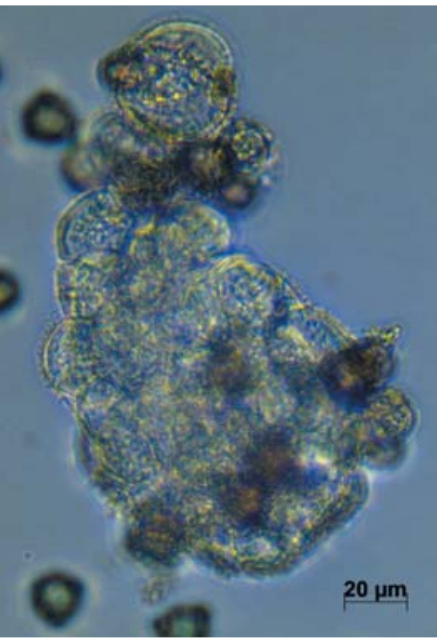

$\boldsymbol{E}$

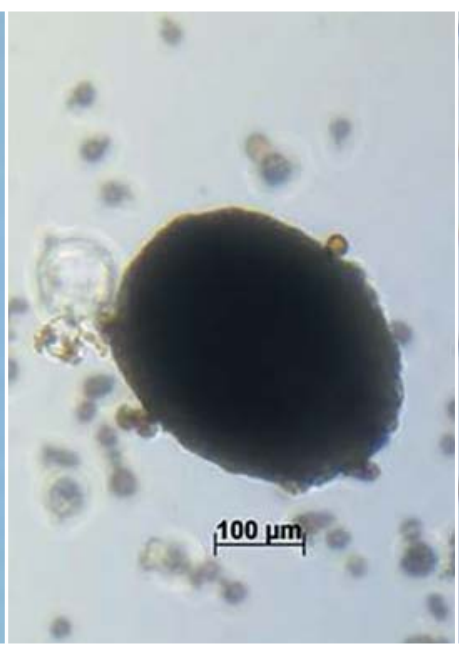

B

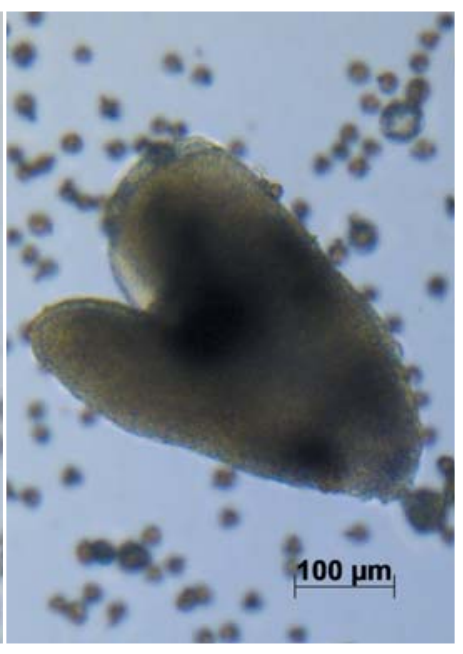

$\Gamma$

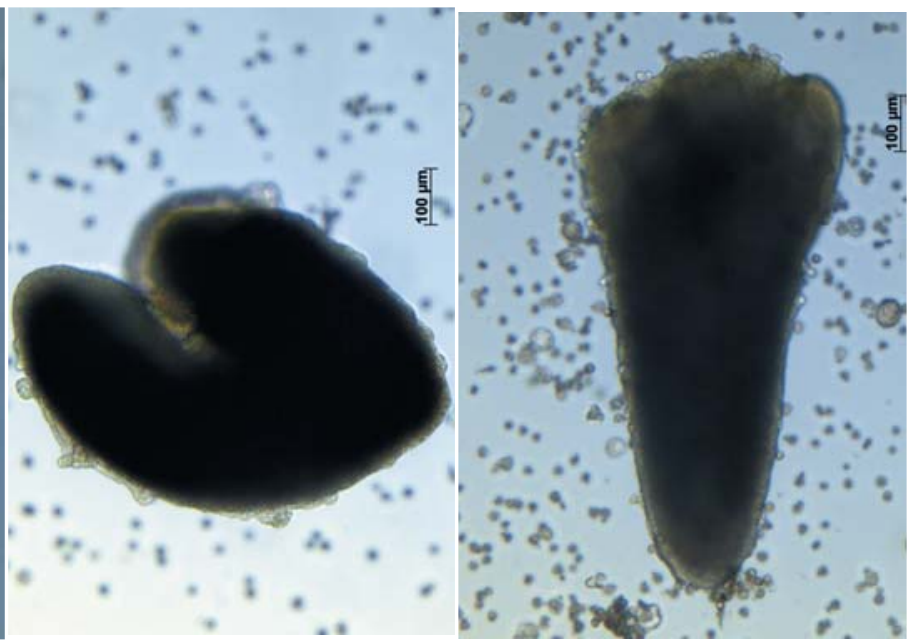

ж
3

Рис. 1. Развитие эмбриоидов в культуре микроспор Brassica juncea (A-Г) и Eruca sativa (Д-3): А, Д - первые деления в культуре микроспор (4 суток); Б, Е-деления (6 суток); В - эмбриоид на глобулярной стадии развития (8 суток); $\Gamma$, Ж - эмбриоид на сердцевидной стадии развития (12 суток); 3 - эмбриоид на ранней семядольной стадии развития (14 суток)

Fig. 1. Embryoid development in culture microspore of Brassica juncea (А- $Г$ ) and Eruca sativa (Д-3): $A, \mathcal{A}$ - First division of microspore after 4 days of culture; $\overline{5}, E$ - division after 6 days of culture $B$ - embryoid at the globule stage after 8 days of culture; $\Gamma$, $\mathcal{X}$-embryoid at the heart-shaped stage after 12 days of culture; 3 - embryoid at the early cotyledonary stage after 14 days of culture

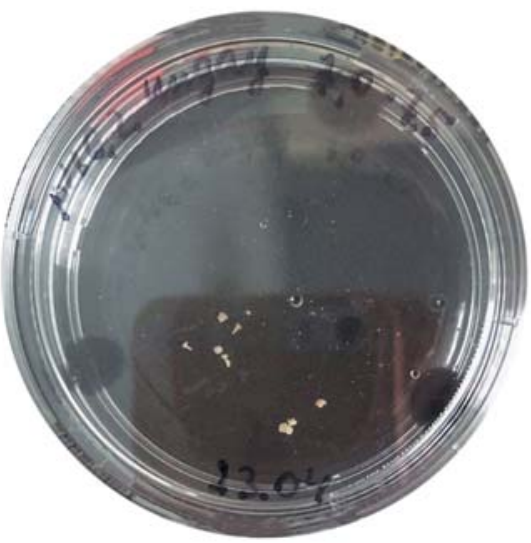

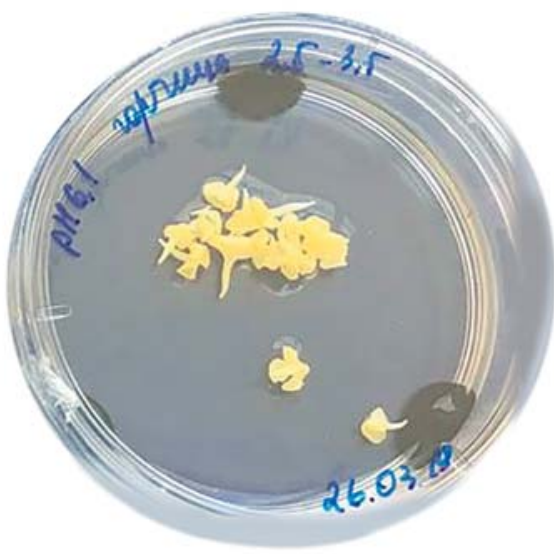

Рис. 2. Образовавшиеся в культуре микроспор эмбриоиды

на семядольной стадии развития на жидкой питательной среде NLN-13:

A - индау посевной (Eruca sativa), Б - горчица сарептская (Brassica juncea)

Fig. 2. Microspore-derived embryods at the cotyledon stage on the NLN-13 liquid medium $A$ - rocket salad (Eruca sativa), $\mathrm{E}$ - sarepta mustard (Brassica juncea) 


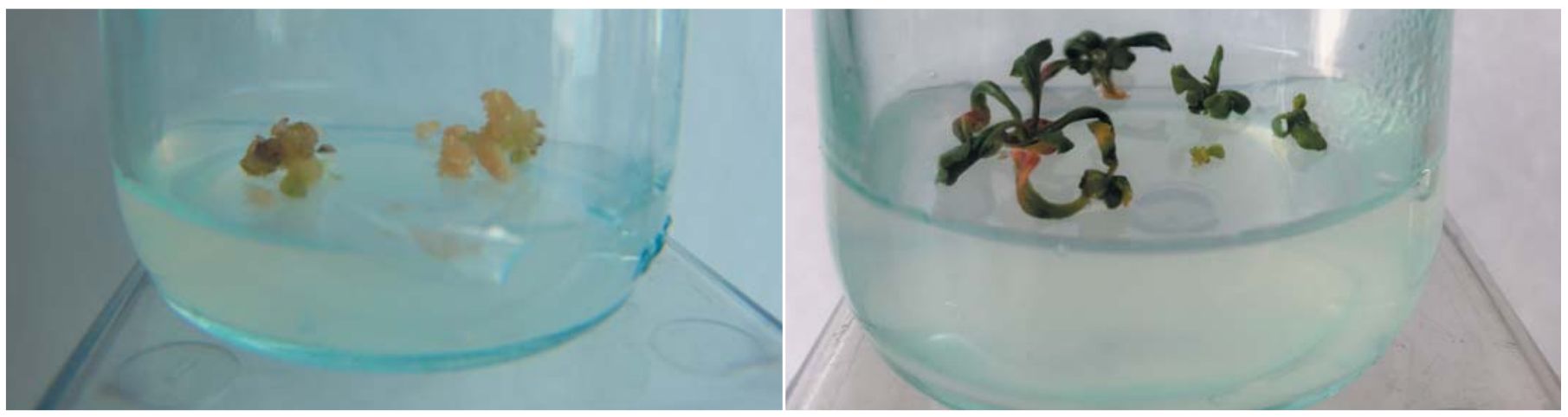

$\boldsymbol{A}$

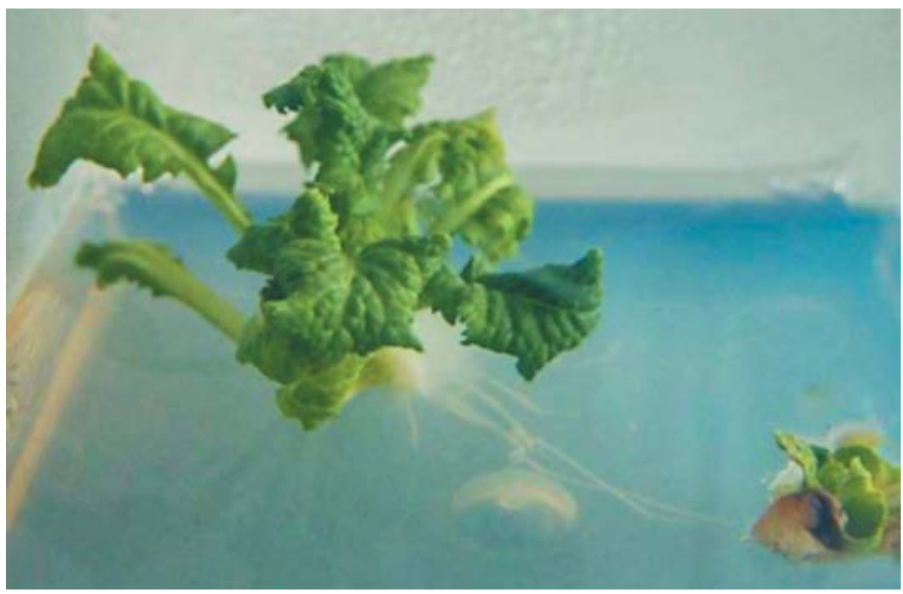

B

Рис.3. Регенерация в культуре in vitro A, Б - индау посевной (Eruca sativa); В, Г - горчица сарептская (Brassica јuncea) Fig. 3. Plantlet regeneration in vitro

$A, \bar{B}$ - rocket salad (Eruca sativa), B, $\Gamma$ - sarepta mustard (Brassica juncea)

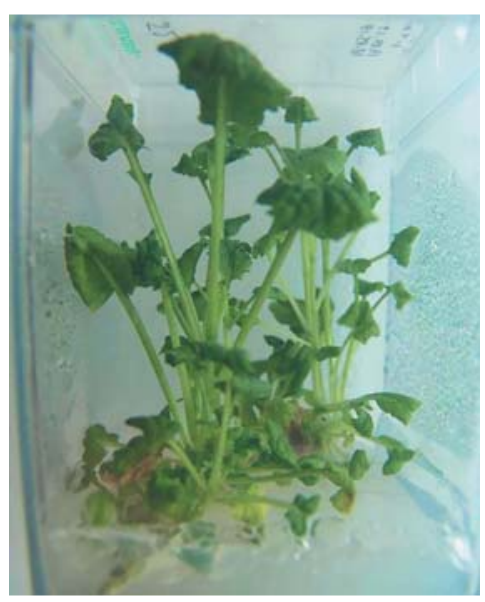

$\Gamma$

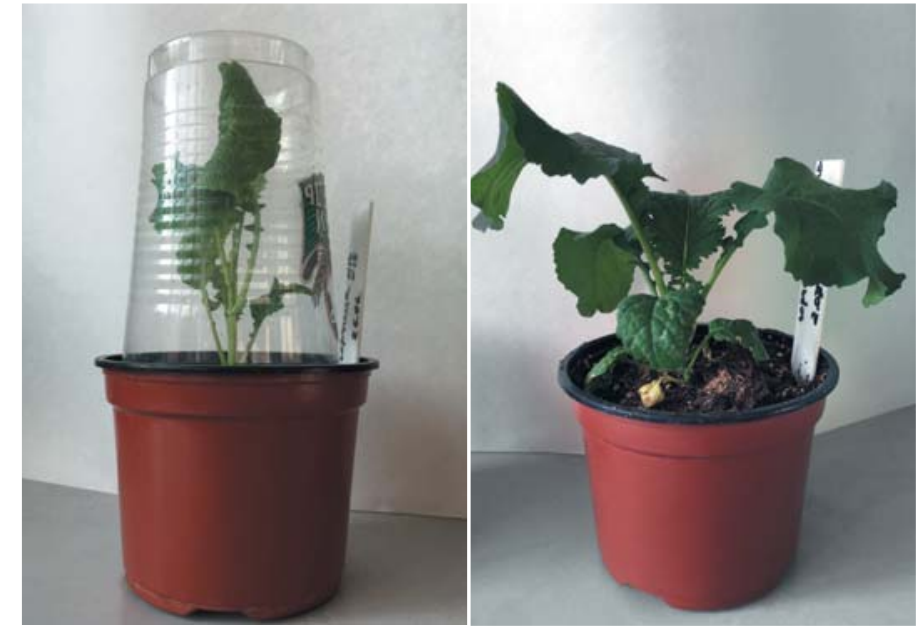

Рис.4. Адаптация растений-регенерантов горчицы к условиям in vivo Fig. 4. Adaptation of plants-regenerants in vivo

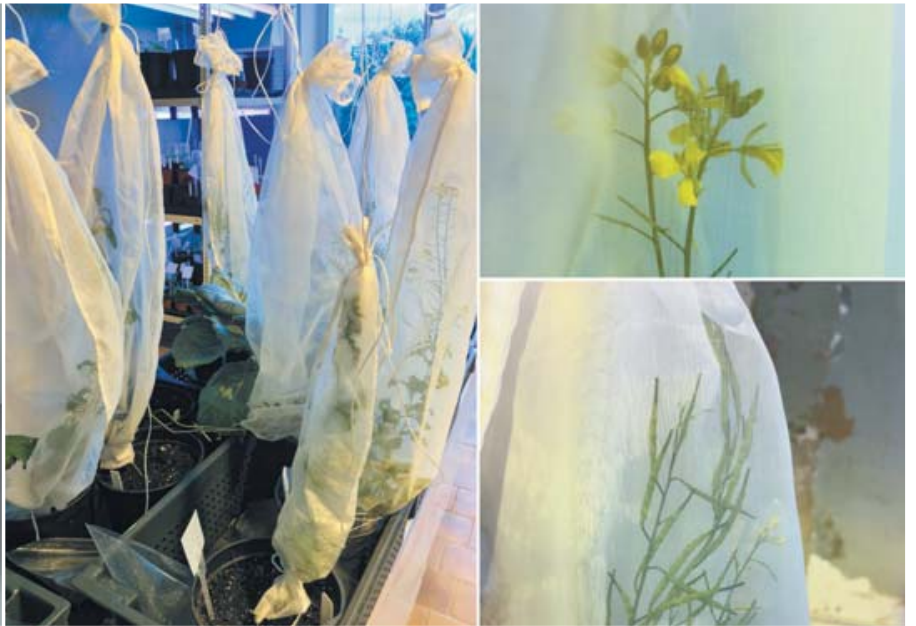

Рис. 5. Цветущее растение $\boldsymbol{R}_{0}$ Fig 5. Flowering plant $\boldsymbol{R}_{0}$
Оптимальное значение $\mathrm{pH}$ для большинства растительных тканей лежит в пределах 5,0-5,5 [19]. В исследованиях некоторых авторов было показано, что относительно высокое значение рН питательной среды $(6,2-6,4)$ у большинства генотипов капустных культур более эффективно для индукции эмбриогенеза из микроспор [20]. В проведенных нами исследованиях для большинства образцов наиболее благоприятным оказалось значение $\mathrm{pH}$ среды NLN-13, равное 6,1 (рис.2). Выход эмбриоидов при этом достигал у горчицы сарептской до 25-30 шт./5 бутонов, а у индау посевного - до 5-7 шт./5 бутонов. Эмбриоиды горчицы сарептской на семядольной стадии развития были значительно крупнее по размеру, по сравнению с индау посевным, и развивались быстрее.

Первые деления мы наблюдали на 4 сутки культивирования (рис. 1 A), на 6 сутки отмечено формирование многоклеточного эмбриогенного класте- ра с 5-10 ядрами (рис. 1 Б), а уже на 8 сутки - эмбриоида на глобулярной стадии развития. На 14 сутки эмбриоид достигает ранней семядольной стадии (рис.1 Д). После переноса образовавшихся эмбриоидов на твердую безгормональную среду была отмечена быстрая прямая регенерация и успешное развитие с множественным побегообразованием растений-регенерантов горчицы сарептской в течение 2-х недель (рис. 3 В, Г). У индау посевного при поме- 
щении эмбриоидов на регенерационную среду часто наблюдалась более длительная регенерация побегов через образование каллуса и вторичный эмбриогенез (рис.3 А, Б). С учетом потерь на этапе регенерации и адаптации (рис.4) всего в 2019 году было получено 32 линии удвоенных гаплоидов горчицы сарептской (рис.5) и 3 линии индау посевного.

\section{Заключение}

В результате проведенных исследований модифицирован базовый протокол культуры изолированных микроспор in vitro для горчицы сарептской и индау посевного российской селекции. Подобрано оптимальное сочетание стрессовых факторов, условий культивирования для индукции эмбриогенеза у изученных сортообразцов. Благодаря оптимиза- ции методики весь биотехнологический цикл от введения микроспор в культуру in vitro до образования семян у удвоенного гаплоида занимает 4-5 месяцев, что существенно сокращает селекционный процесс. Все полученные линии удвоенных гаплоидов переданы в лабораторию селекции и семеноводства зеленных и пряно-вкусовых культур ФГБНУ ФНЦО для дальнейшей селекционной работы.

\section{Об авторах:}

Домблидес Елена Алексеевна - кандидат с.-х. наук, зав. лабораторией репродуктивной биотехнологии в селекции сельскохозяйственных растений https://orcid.org/0000-0002-2695-190X

Чичварина Ольга Александровна - М.н.с. лаборатории

репродуктивной биотехнологии в селекции сельскохозяйственных растений https://orcid.org/0000-0001-5297-2969

Минейкина Анна Игоревна - кандидат с.-х. наук, н.с. лаборатории репродуктивной биотехнологии в селекции сельскохозяйственных растений https://orcid.org/0000-0001-9864-1137

Курбаков Евгений Леонидович - кандидат с.-х. наук, С.н.с. лаборатории селекции и семеноводства зеленных, пряно-вкусовых и цветочных культур Харченко Виктор Александрович - кандидат С.-Х. наук, зав. лабораторией селекции и семеноводства зеленных, пряно-вкусовых и цветочных культур https://orcid.org/0000-0003-2775-9140

Домблидес Артур Сергеевич - кандидат с.-х. наук

зав. лабораторией генетики и цитологии

https://orcid.org/0000-0002-5617-9498

Солдатенко Алексей Васильевич - доктор с.-х. наук,

проф. РАН, главный н.С., директор

https://orcid.org/0000-0002-9492-6845

\section{- Литература}

1. Елисеева О.В., Елисеев А.Ф. Химический состав Eruca sativa (Mill.) Diplotaxis tenuifolia (L.) DC. // Доклады TCXA. Рос. гос. аграр. ун-т - МСXА им К. А. Тимирязева, 2018; в.290. 4.4. - С.352-353.

2. Лудилов В.А., Иванова М.И. Редкие и малораспространенные овощные культуры (биология, выращивание, семеноводство): производственнопрактическое издание - М : ФГНУ «Росинформагротех», 2009 - 196 с.

3. Пивоваров В.Ф. Овощи России. - М.: ГНУ ВНИИССОК, 2006. - 384 с.

4. Государственный реестр селекционных достижений, допущенных к использованию. Т.1. «Сорта растений» (официальное издание). - М.: ФГБНУ «Росинформагротех», 2019.

5. Гиренко М.М., Зверева О.А. Зеленные овощи. М.: Издательство «Ниола Пресс»; Издательский дом «ЮНИОН-паблик», 2007. - 176 с.

6. iFarm project. Всё пучком. Российский рынок свежей зелени и овощей бла гоприятен для вложения инвестиций. URL: http://www. ifarmproject.ru/russiangreenmarket.

7. ROIF EXPERT, 6 ДЕКАБРЯ 2018. Рынок свежей зелени в России: импорт свежей зелени приблизится к 100 млн. \$ отметке // РБК Магазин исследований. URL: https://www.marketing.rbc.ru/articles/10602/.

8. Pechan, P.M., Keller W.A. Identification of potentially embryogenic microspores in Brassica napus. Physiol Plant:; 1988. Vol.74 - P. 377-384.

9. Agnihotri A., Seguin-Swartz G., Dovney R.K. Microspore embryogenesis in $B$. juncea. In: Pareek L.K., ed. Trends in plant tissue culture and biotechnology. Rajasthan, India: Agrobotanical Publishers; 1996: 218-221.

10. Hiramatsu M.; Odahara K.; Matsue Y. A survey of microspore embryogenesis in leaf mustard (Brassica juncea). Acta Hort. 392:139-145; 1995.

11. Lionneton E.; Beuret W.; Delaitre C.; Ochatt S.; Rancillae M. Improved microspore culture and doubled haploid plant regeneration in the brown condiment mustard (B. juncea). Plant Cell Rep. 20:126-130; 2001.

12. Prem, D., Gupta, K., Agnihotri, A. Effect of various exogenous and endogenous factors on microspore embryogenesis in Indian mustard (Brassica juncea (L.) Czern and Coss). In Vitro Cell.Dev.Biol.-Plant (2005) 41: 266.

13. Leskovsek L., Jakse M., Bohanec B. Doubled haploid production in rocket Eruca sativa Mill.) through isolated microspore culture. Plant. Cell. Tiss. Organ Cult. (2008) 93:181-189.

14. Alexander M.P. Differential staining of aborted and non-aborted pollen. Stain technol. - 1969. - Vol.44. - P.117-122.

15. Домблидес Е.А., Шмыкова Н.А., Шумилина Д.В., Заячковская Т.В., Минейкина А.И., Козарь Е.В., Ахраменко В.А., Шевченко Л.Л., Кан Л.Ю., Бондарева Л.Л., Домблидес А.С. Технология получения удвоенных гаплоидов в культуре микроспор семейства капустные (методические рекомендации) / Коллектив авторов. /Изд-во ВНИИССОК. - 2016. - 40 с.

16. Gamborg, O.L. Nutrients requirements of suspension cultures of soybean roo cells / Gamborg O.L., Miller R.A., Ojima K. // Exp Cell Res. - 1968. - Vol.50. - P. 151-158.

17. Huang B., Bird S., Kemble R., Simmonds D. Effects of culture density, conditioned medium feeder cultures on microspore embryogenesis in Brassica napus L. cv. Topas / B. Huang, // Plant Cell Rep. - 1990. - Vol.8. - P.594-597.

18. Touraev A., Brian P. Forster, S. Mohan Jain. Advances in Haploid Production in Higher Plants. Springer Science, Business Media B.V. - 2009. - P. 347.

19. Бутенко, Р.Г. Биология клеток высших растений in vitro и биотехнологии на их основе: учебное пособие / Р.Г. Бутенко. - М.: ФБК-ПРЕСС, 1999. - 160 с.

20. Yuan, S.X. Effects of pH, MES, arabinogalactan-proteins on microspore cultures in white cabbage / S.X. Yuan, Y.B. Su, Y.M. Liu // Plant Cell Tiss Organ Cult. - 2012. - Vol.110. - P.69-76

\section{About the authors:}

Elena A. Domblides - Ph.D. in Agriculture, Head of Laboratory of Reproductive Biotechnology in Crop Breeding

Olga A. Chichvarina - Junior Researcher of Laboratory

of Reproductive Biotechnology in Crop Breeding

Anna I. Mineykina - Ph.D. in Agriculture, Researcher

of Laboratory of Reproductive Biotechnology in Crop Breeding

Evgeniy L. Kurbakov - Ph.D. in Agriculture,

Senior Researcher, Aromatic and Leafy Vegetable Crops

Viktor A. Kharchenko - Ph.D. in Agriculture Head

of Laboratory of Aromatic and Leafy Vegetable Crops

Arthur S. Domblides - Ph.D. in Agriculture,

Head of Laboratory of Genetics and Cytology

Alexey V. Soldatenko - doctor of agricultural Sciences,

Professor of the Russian Academy of Sciences, chief researcher

\section{- References}

1. Eliseeva O.V., Eliseev A.F. The chemical composition of Eruca sativa (Mill.) and Diplotaxis tenuifolia (L.) DC. // Reports of the TAA. Moscow Timiryazev Agricultural Academy Rep. 2018; v.290, p.4. - P.352-353. (In Russ.)

2. Ludilov V.A., Ivanova M.I. Rare and rare vegetables (biology, cultivation, seed production): Instructional Edition. - M.: FGNU "Rosinformagrotekh", 2009. - 196 p. (In Russ.)

3. Pivovarov V.F. Vegetable crops of Russia. M.: VNIISSOK, 2006. - 384 p. (In Russ.)

4. The state register of breeding achievements approved for use. T.1. "Plant Varieties" (official publication). - M.: RosInformagrotekh, 2019. (In Russ.)

5. Girenko M.M., Zvereva O.A. Green vegetables. M.: Publishing house "Niola Press"; Publishing house "UNION-Public", 2007. - 176 p. (In Russ.)

6 . iFarm project. The Russian market of fresh herbs and vegetables is favorable for investments. URL: http://www.ifarmproject.ru/russiangreenmarket. (In Russ.) 7. ROIF EXPERT, DECEMBER 6, 2018. Market for fresh greens in Russia: imports of fresh greens close to $\$ 100$ million. // РБK Магазин исследований. URL: https://www.marketing.rbc.ru/articles/10602/. (In Russ.)

8. Pechan, P.M., Keller W.A. Identification of potentially embryogenic microspores in Brassica napus. Physiol Plant - 1988 - Vol 74 - P 377-384.

9. Agnihotri A., Seguin-Swartz G., Dovney R.K. Microspore embryogenesis in B. juncea. In: Pareek L.K., ed. Trends in plant tissue culture and biotechnology. Rajasthan, India: Agrobotanical Publishers; 1996: 218-221.

10. Hiramatsu M.; Odahara K.; Matsue Y. A survey of microspore embryogenesis in leaf mustard (Brassica juncea). Acta Hort. 392:139-145; 1995.

11. Lionneton E. Beuret W. Delaitre C. Ochatt S: Rancillae M. Improved microspore culture and doubled haploid plant regeneration in the brown condiment mustard (B. juncea). Plant Cell Rep. 20:126-130; 2001.

12. Prem, D., Gupta, K., Agnihotri, A. Effect of various exogenous and endogenous factors on microspore embryogenesis in Indian mustard (Brassica juncea (L.) Czern and Coss). In Vitro Cell.Dev.Biol.-Plant (2005) 41: 266.

13. Leskovsek L., Jakse M., Bohanec B. Doubled haploid production in rocket Eruca sativa Mill.) through isolated microspore culture. Plant. Cell. Tiss. Organ. Cult. (2008) 93:181-189.

14. Alexander M.P. Differential staining of aborted and non-aborted pollen. Stain technol. - 1969. - Vol.44. - P.117-122.

15. Domblides E.A., Shmykova N.A., Shumilina D.V., Zayachkovskaya T.V., Mineykina A.I., Kozar E.V., Akhramenko V.A., Shevchenko L.L., Kan L.Yu., Bondareva L.L., Domblides A.S. Technology for producing doubled haploids in the culture of microspores of the cabbage family (methodical recommendations) / Publishing house VNIISSOK. - 2016. - 40 p. (In Russ.)

16. Gamborg, O.L. Nutrients requirements of suspension cultures of soybean root cells / Gamborg O.L., Miller R.A., Ojima K. // Exp Cell Res. - 1968. - Vol.50.

- P.151-158.

17. Huang B., Bird S., Kemble R., Simmonds D. Effects of culture density, conditioned medium feeder cultures on microspore embryogenesis in Brassica napus L. cv. Topas / B. Huang, // Plant Cell Rep. - 1990. - Vol.8. - P.594-597.

18. Touraev A., Brian P. Forster, S. Mohan Jain. Advances in Haploid Production in Higher Plants. Springer Science, Business Media B.V. - 2009. - P.347.

19. Butenko, R.G. Biology of cells of higher plants in vitro and biotechnologies based on them: a tutorial / R.G. Butenko. - M.: FBK-PRESS, 1999. - 160 p. (In Russ.)

20. Yuan, S.X. Effects of $\mathrm{pH}$, MES, arabinogalactan-proteins on microspore cultures in white cabbage / S.X. Yuan, Y.B. Su, Y.M. Liu // Plant Cell Tiss Organ Cult. - 2012. - Vol.110. - P.69-76. 